\title{
Techno Economic Analysis of Hybrid Sea Floating Photovoltaic and Wind Turbine for Fish Cold Storage At Remote Island In Indonesia (Case Study: Small Kei Island, Maluku, Indonesia)
}

\author{
Fidel Rezki Fajry ${ }^{1}$, Iwa Garniwa ${ }^{*}$, Achmad Fajar Tofani ${ }^{1}$ \\ ${ }^{1}$ Department of Electrical Engineering, Universitas Indonesia, Jakarta, Indonesia
}

\begin{abstract}
Most of fisherman in Small Kei Island, Indonesia, are difficult to keep the good quality of fish for several days because unavailability of Fish Cold Storage. Due to the area is also far from grid, this paper is aimed to analyse the most optimized sizing of integrating the new technology of sea floating photovoltaic and wind turbine to achieve the minimal levelized cost of energy for powering 100 tons of fish cold storage. Ten scenarios with implemented off-grid scheme by dividing battery bank into two equal parts that will be operated interchangeably to meet 24 hours load requirement on hybrid sea floating photovoltaic and wind turbine system are performed. As result, $100 \mathrm{~kW}$ of wind turbine and $803 \mathrm{kWp}$ of sea floating photovoltaic are chosen with the most minimal levelized cost of energy of USD $0.52 / \mathrm{kWH}$ by life cycle cost method of 20 years. With define electricity tariff of USD $0.81 / \mathrm{kWH}$ and interest loan of $9 \%$, the economic analysis result fulfil of four indicators requirement with payback period of 6 years 6 months 20 days, net present value of USD 10,981, internal rate of return of $9.10 \%$, and profitability index of 1.60 .
\end{abstract}

\section{Introduction}

Fish cold storage can preserve fish for a long period and ensure the fish quality is in a good quality. In 2016, the installed fish cold storage in Indonesia is only reached $11.49 \%$ of total demand [1]. One of the main problem is due to the electricity which is not distributed. Hence, those areas need standalone power generation for fish cold storage. Nowadays, the type of power generation from renewable energy is proposed to be developed. It is appropriate with PT. Perusahaan Listrik Negara that prioritizes to utilize renewable power generation to supply electricity in remote areas, mainly for those are far from grid.

Studies related to cold storage powered by integrating renewable power generation are quite scarce in open literature. The two tons of Fish Cold Storage powered Photovoltaic (COSPV) is proposed in [2]. The PV system scheme is on-off grid and have focused to obtain the estimation cost of COSPV. A rooftop solar PV - diesel generator hybrid mini

*Corresponding author: garniwa@gmail.com 
cold storage for rural area is proposed in [3]. The PV system scheme is on grid. The running concept of cold storage is by consuming power from the roof top solar PV panel, and the diesel generator will be only absorbed during night time. The consideration focused on financial analysis and costing. Then, a conceptual model of a cold storage warehouse powered by on grid PV and grid in smart grid setting is presented in [4]. The system allows the cold storage to withdraw power from the grid and feed power to the grid. A formula with linear programming is used as an optimization to investigated optimal energy management strategies under different tariff scenario.

On recent technology, sea floating photovoltaic (SFPV) has been developed [5]. SFPV system can increase efficiency due to reflection of light from the water and the PV panel temperatures is maintained lower by the natural evaporative cooling from waterbody [6].

On this paper, the objective is to analyse the optimum size of an off-grid hybrid sea floating photovoltaic (SFPV) and wind turbine by setting the power capacity of both renewable generation to achieve the minimum levelized cost of energy (LCOE) for powering DC Fish Cold Storage in Small Kei Island, Indonesia. However, according to economic analysis, SFPV and Wind Turbine with off-grid concept for powering DC fish cold storage are feasible to be developed.

\section{Energy Resource and Load Profile Data}

The load profile of one hundred tons of Fish Cold Storage is shown on Fig. 1. The peak load of $49 \mathrm{~kW}$ is occurred almost eighteen hours during the main freezing load of compressor, condenser, and evaporator running from 6:00AM to 11:59PM. The six (6) hours remain of $16.7 \mathrm{~kW}$ is the recovery period when defrost running from 00:00 to 5:59AM. Another load is consisted of lighting, heating, mechanical handling equipment, etc.

The annual of both daily solar radiation and wind speed data in Small Kei Island are $5.57 \mathrm{kWh} / \mathrm{m} 2 /$ day $(232 \mathrm{~W} / \mathrm{m} 2)$ and $4.0 \mathrm{~m} / \mathrm{s}$, which were collected from Atmospheric Science Data Center that refer to NASA [7].

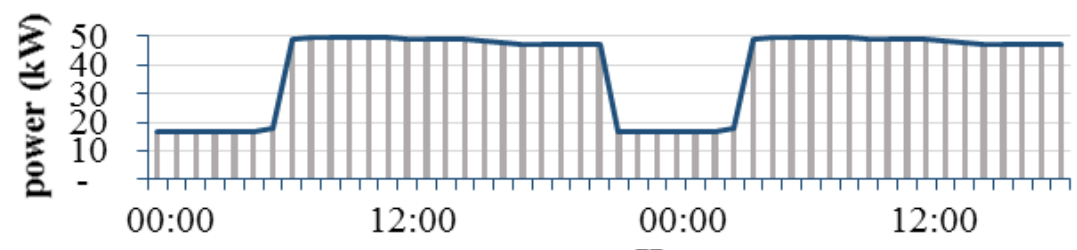

(a)

Hour
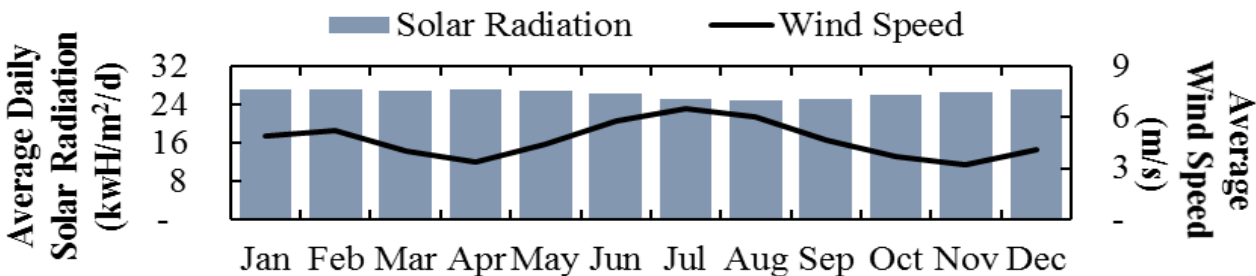

Jan Feb Mar AprMay Jun Jul Aug Sep Oct Nov Dec

\section{Month}

(b)

Fig. 1. (a) daily load curve of 100 tons of fish cold storage, (b) monthly average daily solar radiation and wind speed at Small Kei Island 


\section{Component Sizing of Hybrid System and LCOE Calculation}

The proposed hybrid SFPV and wind turbine system uses off-grid scheme as shown on Fig 2. The off-grid system configuration uses two equal battery banks that will be operated interchangeably with the strategy schedule of operation as shown on Table 2. Each of battery bank will be charged and discharge for 24 hours. The purposed is to make sure that the battery can be fully operated when the weather is unpredictable and meet load requirement for daily 24 hours basis. During discharged, the battery banks will be cut-off if the remain of capacity achieve $30 \%$ from total capacity. After obtained the load requirement, the sizing of hybrid system is started from battery bank, wind turbine, and SFPV module as mentioned on below.

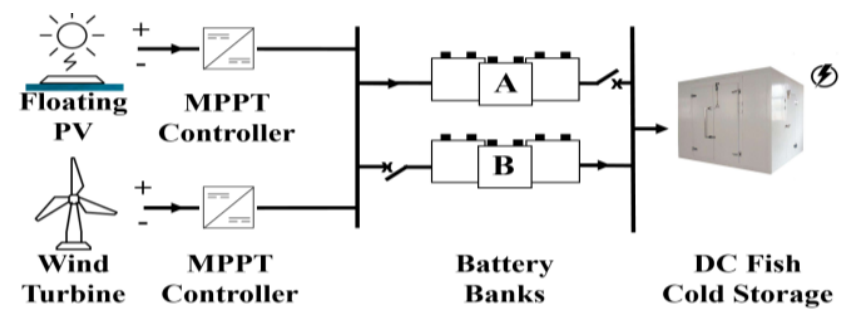

Fig. 2. Block diagram of the proposed hybrid SFPV and wind turbine

\subsection{Sizing Battery Banks}

The total capacity of battery banks per unit (Cap) can be calculated from the total load demand (TLD), Depth of Discharge (DOD), and the day without sun (dws) as derived:

$$
\operatorname{Cap}_{(V A H)}=\frac{T L D_{(k w h / d a y)} * d w s_{(\text {day })}}{D O D}
$$

\subsection{Sizing Wind Turbine}

A wind turbine generator can start generating power if the wind speed $(v)$ exceeds the cut-in value $\left(V_{i}\right)$. Then, it will generate the rated power $\left(P_{\text {rated }}\right)$ if the wind speed exceed the rated speed $\left(V_{r}\right)$ of the wind turbine. It will stop if the wind speed exceeds the cut-out $\left(V_{o}\right)$ value to protect generator [3]. The power output of Wind Turbine $\left(\mathrm{P}_{\mathrm{WT}}\right)$ is expressed as [8]:

$$
\begin{array}{ll}
P_{\text {wind }}=0 & \text { if } v \leq V_{i} \text { or } v \geq V_{o} ; \\
P_{\text {wind }}=P_{\text {rated }} \eta_{\text {turbine }} \frac{v-V_{i}}{V_{r}-V_{i}} & \text { if } V_{i}<v<V_{r} ; \\
P_{\text {wind }}=P_{\text {rated }} & \text { if } V_{r}<v<V_{o} ;
\end{array}
$$

Table 2. The strategy schedule scenario of battery banks operation

\begin{tabular}{llllllllll}
\hline Day & \multicolumn{1}{c}{ 1st } & \multicolumn{2}{c}{ 2nd } & \multicolumn{3}{c}{ 3rd } & \multicolumn{3}{c}{ 4th } \\
\hline Time & $\mathrm{O}$ & $\mathrm{C}$ & $\mathrm{O}$ & $\mathrm{C}$ & $\mathrm{O}$ & $\mathrm{C}$ & & \\
Battery A & $\mathrm{X}$ & $\mathrm{X}$ & $\mathrm{V}$ & $\mathrm{V}$ & $\mathrm{X}$ & $\mathrm{X}$ & $\mathrm{V}$ & $\mathrm{V}$ \\
Battery B & $\mathrm{V}$ & $\mathrm{V}$ & $\mathrm{X}$ & $\mathrm{X}$ & $\mathrm{V}$ & $\mathrm{V}$ & $\mathrm{X}$ & $\mathrm{X}$ \\
\hline
\end{tabular}


Table 3. Small Kei Island Site \& Environmental Data

\begin{tabular}{llc}
\hline Description & Requirement of Floating PV & Small Kei Island Data [9] \\
\hline $\begin{array}{l}\text { Water depth } \\
\text { (low tidal) }\end{array}$ & Minimum 1 m, optimal 3-10 m, & $2.75 \mathrm{~m}$ \\
Waves & maximum 25m & \\
& At $1-3 \mathrm{~m}$ depth maximum 0.5 m waves, & $0.5 \mathrm{~m}$ \\
Wind Speed & At depth $>3 \mathrm{~m}$ maximum $1.5 \mathrm{~m}$ waves & \\
Water Current & Maximum $100-120 \mathrm{~km} / \mathrm{h}$ & $14.4 \mathrm{~km} / \mathrm{h}$ \\
Seabed & Maximum $8 \mathrm{~km} / \mathrm{h}$ & $0.54 \mathrm{~km} / \mathrm{h}$ \\
& Preferably Sand, mud, or rubble. & Sandy \\
\hline
\end{tabular}

\subsection{Sizing Solar Floating Photovoltaic (SFPV) Module}

SFPV system concept removes big land requirement. If inland PV requires requirement on civil and trenching, SFPV requires platform, mooring system, and under-water cable as described on [6]. On this paper, the reason to utilize SFPV is due to the site \& environmental data of Small Kei Island fulfil the requirement to install SFPV as shown on Table 3, and have better efficiency of module compare to inland PV due to water cooling effect.

Each of SFPV module has the capacity of $24 \mathrm{kWp}$ that consists of 96 units of $250 \mathrm{~kW}$ panels. To calculate the required power generation of SFPV shall consider the average effective time $\left(\mathrm{E}_{\mathrm{ff}}\right)$ of solar radiation in Small Kei Island, which is 4.5 hours per day [10], the average of PV panel efficiency $\left(\eta_{P V \text { module }}\right)$ according to recent research, which is $17 \%$, and charge controller efficiency $\left(\eta_{M P P T}\right)$. The real capacity of SFPV $\left(\mathrm{Cap}_{S F P V}\right)$ can be expressed as follows:

$$
\operatorname{Cap}_{S F P V(k W p)}=\left[\left(\frac{\operatorname{Cap}_{(V A H)}}{d w s_{(\text {day })}}\right)-W_{T(k W H / d a y)}\right] * E_{f f(h / \text { day })} * \eta_{\mathrm{PVmodule}} * \eta_{M P P T}
$$

\subsection{LCOE Calculation}

To compare different capacities of electricity generation on a comparable basis, LCOE [11] with 20 years lifetime project is calculated as follows:

$$
\operatorname{LCOE}_{\left(\frac{U S D}{k W H}\right)}=\frac{\text { Life Cycle Cost }(L C C)_{(U S D)}}{\text { Lifetime energy production }}
$$

The LCC is obtained refer to unit cost as shown on Table 5 on below.

Table 5. Unit cost of hybrid SFPV \& wind turbine system

\begin{tabular}{lrrr}
\hline \multirow{2}{*}{ Description } & \multicolumn{3}{c}{ Unit Cost } \\
\cline { 2 - 4 } & $\begin{array}{c}\text { SFPV } \\
\text { (USD / kW })\end{array}$ & $\begin{array}{c}\text { Wind Turbine } \\
\text { (USD / kW) }\end{array}$ & $\begin{array}{c}\text { Battery } \\
\text { (USD/kVAH) }\end{array}$ \\
\hline Material & 270.00 & $2,274.00$ & 220.00 \\
Grid Connection & 150.00 & 350.00 & Included \\
Construction & 236.00 & 560.00 & 39.65 \\
Other Cost & 410.00 & 350.00 & N/A \\
Land Cost & 4.00 & 60.00 & N/A \\
O\&M Cost & 10.72 & 898.00 & 545.79 \\
\hline
\end{tabular}




\section{Result And Discussion}

The results of the optimal sizing simulation are presented according to various combination power of SFPV and wind turbine with 10 scenarios as shown on Table 4. Increasing the capacity of wind turbine creates impact on SFPV capacity that is decreased as the compensation to meet total load requirement. Then, the LCOE is reduced when the capacity of wind turbine is increased and the capacity of SFPV is decreased. It can be understood that SFPV has both LCC and LCOE greater than wind turbine because it has greater capacity to compensate the effect from effective time of radiation solar which is only 4-5 hours per day. Then with the concept of using two equal battery banks that operated interchangeably, using typical battery bank of flooded lead acid with cycle of 2430, the battery banks has lifetime of 6.67 years and need additional 2 times replacement during project lifetime of 20 years. It makes the O\&M cost of Battery banks become greats and make the LCOE of off-grid hybrid renewable power generation become expensive. As result, the hybrid system of $100 \mathrm{~kW}$ wind turbine and $803 \mathrm{kWp}$ SFPV is chosen with the most minimal LCOE of USD $0.52 / \mathrm{kWH}$.

Table 4. Simulation result of optimization hybrid SFPV \& Wind Turbine

\begin{tabular}{|c|c|c|c|c|c|c|c|c|c|}
\hline \multirow{2}{*}{ Scenario } & \multirow{2}{*}{$\begin{array}{c}\text { Total } \\
\text { Load } \\
(\mathrm{kWh} / \\
\text { day) }\end{array}$} & \multicolumn{3}{|c|}{$\begin{array}{c}\text { Battery Bank } \\
\text { Capacity per Unit }\end{array}$} & \multicolumn{2}{|c|}{ Wind Turbine } & \multicolumn{2}{|r|}{ SFPV } & \multirow{2}{*}{$\begin{array}{l}\text { LCOE } \\
\text { (USD/ } \\
\text { kWh) }\end{array}$} \\
\hline & & V & AH & DOD & $\begin{array}{c}\text { Rated } \\
(\mathbf{k W})\end{array}$ & $\begin{array}{c}\text { Output } \\
(\mathrm{kWh} / \text { day })\end{array}$ & $\begin{array}{l}\text { Rated } \\
(\mathbf{k W p})\end{array}$ & $\begin{array}{c}\text { Output } \\
\text { (kWh/day) }\end{array}$ & \\
\hline 1 & 943.88 & 48 & 28,0 & 1 & 10 & 76.50 & 1,751 & $1,271.89$ & .616 \\
\hline 2 & 3.88 & 48 & 28,092 & $70 \%$ & 20 & 01 & 1,645 & 1,1 & 0.606 \\
\hline 3 & 943.88 & 48 & 28,092 & $70 \%$ & 30 & 229.51 & 1,540 & $1,118.88$ & 0.596 \\
\hline 4 & 943.88 & 48 & 28,092 & $70 \%$ & 40 & 306.01 & 1,435 & $1,042.38$ & 0.585 \\
\hline 5 & 943.88 & 48 & 28,092 & $70 \%$ & 50 & 382.52 & 1,330 & 965.88 & 0.575 \\
\hline 6 & 943.88 & 48 & 28,092 & $70 \%$ & 60 & 459.02 & 1,224 & 889.37 & 0.564 \\
\hline 7 & 943.88 & 48 & 28,092 & $70 \%$ & 70 & 535.52 & 1,119 & 812.87 & 0.553 \\
\hline 8 & 943.88 & 48 & 28,092 & $70 \%$ & 80 & 612.03 & 1,014 & 736.37 & 0.542 \\
\hline 9 & 943.88 & 48 & 28,092 & $70 \%$ & 90 & 688.53 & 908 & 659.86 & 0.531 \\
\hline 10 & 943.88 & 48 & 28,092 & $70 \%$ & 100 & 765.04 & 803 & 583.36 & 0.520 \\
\hline
\end{tabular}

According to data of scenario chosen, we can see that the percentage of energy output $(\mathrm{kWh} /$ day) of both wind turbine and SFPV are $57 \%$ and $43 \%$ from total energy output and meet load requirement for 24 hours as shown on Fig 3.

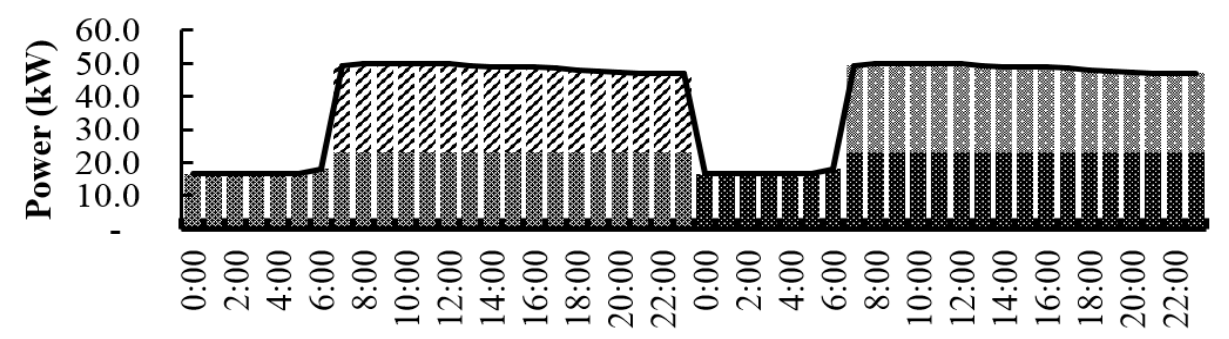

\section{Hours}

Wind Turbine Generation, then supplied by Battery A to load.
SFPV Generation, then supplied by Battery A to load.
SFPV Generation, then supplied by Battery B to load.
Load demand

Fig. 3. Power generation curve of hybrid SFPV and wind turbine 
Define ideal electricity tariff of $0.81 / \mathrm{kWH}$, then interest loan (i) of $9 \%$, the economic analysis on Table 6 shown that hybrid SFPV and wind turbine is feasible to be developed.

Table 6. Economic analysis result of four indicators

\begin{tabular}{lcc}
\hline \multicolumn{1}{c}{ Indicator } & Requirement & Result \\
\hline Payback Period (PBP) & less than project lifetime & 6.56 years \\
Net Present Value (NPV) & $>0$ & USD 10,981 \\
Internal Rate of Return (IRR) & $>\mathrm{i}$ & $9.1 \%$ \\
Profitability Index (PI) & $\geq 1$ & 1.6 \\
\hline
\end{tabular}

\section{Conclusion}

The hybrid system of $100 \mathrm{~kW}$ wind turbine and $803 \mathrm{kWp} \mathrm{SFPV} \mathrm{with} \mathrm{off-grid} \mathrm{scheme} \mathrm{is}$ feasible to be developed for powering fish cold storage in Small Kei Island during 24 hours continuously with minimum LCOE of USD $0.52 / \mathrm{kWH}$. According to scenarios, PV is not recommended to be developed as standalone power generation due to have great capacity and LCOE. However, lower trend price of PV module and battery technology in the future can change the condition and the evaluation of this research results is still required.

The authors gratefully acknowledge the financial support provided by Universitas Indonesia through the 2018 PITTA funding scheme managed by the Directorate of Research and Community Engagement (DRPM UI).

\section{References}

1. Ministry of Marine Affairs and Fisheries Republic of Indonesia, "Indonesia Marine And Fisheries Business And Investment Opportunities", 2017.

2. B.Sena, Fauzun, Indarto, "Cost Estimation in Designing Cold Storage Powered Photovoltaic System (COSPV) for Two Tons of Fish in Indonesia", TEKNOSAINS, vol.12, No.2, 2016.

3. M. R. Khan and S. Iqbal, "Solar PV-diesel hybrid mini cold storage for rural Bangladesh," 2014 3rd International Conference on the Developments in Renewable Energy Technology (ICDRET), Dhaka, 2014, pp. 1-3.

4. R. A. Verzijlbergh and Z. Lukszo, "Conceptual model of a cold storage warehouse with PV generation in a smart grid setting," 2013 10th IEEE International Conference On Networking, Sensing And Control (ICNSC), Evry, 2013, pp. 889-894.

5. SWIMSOL GmbH, "Solar Energy for Tropical Islands", 2015.

6. A. Sahu, N. Yadav, K. Sudhakar, "Floating photovoltaic power plant: A review", Renewable and Sustainable Energy Reviews, vol. 66, 2016, pp. 815-824.

7. Atmospheric Science Data Center. (2018, 3 February 2018). Surface meteorology and Solar Energy - A renewable energy resource web site (release 6.0). Available from: https://eosweb.larc.nasa.gov

8. M. R. Ranjbar, S. Kouhi, "Sources' Response for supplying energy of a residential load in the form of on-grid hybrid systems", International Journal of Electrical Power \& Energy Systems, vol. 64, 2015, pp. 635-645.

9. BMKG Indonesia. (2018, 3 February 2018). Pusat Meteorologi Maritim BMKG - Ocean Forecast System (OFS). Available from: http://peta-maritim.bmkg.go.id/static/

10. Lee, E., "A study of solar installation in Singapore", Schneider Electric - Facilities Management Seminar, 5 August 2011.

11. C. S. Lai and M. D. McCulloch, "Sizing of Stand-Alone Solar PV and Storage System With Anaerobic Digestion Biogas Power Plants," in IEEE Transactions on Industrial Electronics, vol. 64, no. 3, pp. 2112-2121, March 2017. 